The Canadian Journal of Higher Education

La revue canadienne d'enseignement supérieur

Volume XXXI, No. 1, 2001 pages 35-74

\title{
Transfer from Community College to University: Perspectives and Experiences of British Columbia Students
}

\section{LESLEY ANDRES*}

The University of British Columbia

\section{ABSTRACT}

Through formal inter-institutional arrangements, articulated systems of postsecondary education claim to promote equality of opportunity by allowing for a seamless flow of students toward their educational and occupational goals. However, despite system wide articulation of course offerings, numerous studies indicate that the transfer experience is not unproblematic. This paper reports the findings of a qualitative study of the experiences of British Columbia university students who had transferred from community college. The central focus of this study was to portray students' experiences of the transfer process; document difficulties and successes encountered before, during, and after transfer; highlight advantages and disadvantages of transfer; and offer recommendations for improving the transfer process. In 1997, 47 individuals who had transferred from one Lower Mainland Community College to one Lower Mainland University in 1996 were interviewed. The findings revealed that although the majority of students in this study

* The author wishes to acknowledge the support of the B.C. Council on Admissions and Transfer in funding the Investigating Transfer Project and other related projects. 
support transfer as a viable and even preferable route to university degree completion, problems occur at each of the three stages of transfer as specified by Dougherty (1987). Obstacles to successful transfer by students include: difficulty gaining access to useful information; problems understanding transfer policies, practices, and procedures; and declines in GPA following transfer to university. Several recommendations for improving existing transfer policies and practices - including improving access to useful information by students; facilitating transfer through extensive coordination of transfer policies, practices, and procedures; and addressing differences in the teaching and learning experience at sending and receiving institutions - are offered to enhance successful transfer from community college to university.

\section{RÉSUMÉ}

À travers les ententes formelles entre les institutions, les systèmes articulés d'enseignement supérieur prétendent promouvoir l'égalité des chances en laissant un écoulement sans frontières des étudiants vers leurs buts académique et de travail. Cependant, malgré des offres de cours à travers le système, plusieurs études indiquent que l'expérience de ce transfert ne se fait pas sans difficulté. Cette recherche présente les résultats d'une étude qualitative des expériences d'étudiants de l'Université de la Colombie-Britannique qui avaient transférés en provenance des collèges. L'objectif principal de cette étude était de présenter les expériences du processus de transfert des étudiants; de mettre en évidence les difficultés et les succès rencontrés avant, durant, et après le transfert; de démontrer les avantages et les désavantages du transfert; et d'offrir des recommandations pour améliorer le processus du transfert. En 1997, 47 individus qui avaient transféré d'un collège de la région Métropolitaine de Vancouver à une université de la région Métropolitaine en 1996 ont été interviewés. Les résultats indiquent que malgré le fait que la majorité des étudiants sont en faveur du transfert comme chemin possible et même préférable vers l'achèvement du diplôme universitaire, des problèmes sont rencontrés à chacune des trois étapes de transfert comme le démontre Dougherty (1987). Les obstacles 
qui empêchent le transfert des étudiants avec succès incluent: les difficultés à accéder à l'information utile; des difficultés de compréhension des principes, des pratiques et des processus de transfert; et la diminution des notes moyennes après le transfert à l'université. Plusieurs recommandations sont offertes pour promouvoir un transfert réussi du collège à l'université: l'amélioration des principes et des pratiques de transfert qui existent déjà - y compris un meilleur accès à l'information utile pour les étudiants; une facilité du transfert à travers une coordination approfondie des principes, des pratiques et des processus; et l'importance de signifier les différences dans l'expérience d'enseignement et d'apprentissage aux institutions qui envoient et qui reçoivent les étudiants.

In an era of rising tuition rates, burgeoning student loans and increasing calls for accountability, there is mounting pressure to enhance the "seamless" flow of students through the educational system into the work force. Recent provincial policy documents (Report of the Advisory Panel on Future Directions for Postsecondary Education, 1996; Report of the Provincial Access Committee; 1988; Report of the Task Force on Advanced Training, 1993) reinforce the need to eliminate unnecessary obstacles for students desiring to transfer from community college to university.

One way of enhancing student flows is to ensure that an efficient and effective transfer system is in place. In the United States, "effective" transfer has emerged as a key indicator of institutional effectiveness. According to Eaton (1991), transfer effectiveness involves two components: "increasing the number of students who transfer and ensuring their academic achievement" (p. 34). Grubb (1991) claims that "the ability of students to transfer to four-year colleges and then compete as equals against students who begin in four-year colleges is one test of the acceptability of community colleges within higher education" (p. 195).

In most Canadian provinces, university-equivalent courses are generally not available at community colleges and formal provincial articulation arrangements for course transfer are not in place. Three provinces - British Columbia, Alberta and Quebec - have adopted articulated 
models of inter-institutional transfer. In British Columbia and Alberta, transfer systems are similar to most postsecondary systems in the United States. In principle, because articulated systems of postsecondary education have formal inter-institutional agreements in place to permit students with appropriate prerequisites earned at community colleges to transfer to university with recognized credit, they promote equality of opportunity by allowing a seamless flow of students toward their educational and occupational goals. However, it is well documented that despite articulation of course offerings between the two types of institutions, the transfer experience is not unproblematic. The purpose of this paper is to present the results of a British Columbia based study that examines students' transfer experiences within an articulated system of postsecondary education. Through in depth interviews, this study provides a detailed account of students' experiences before, during, and after transfer and offers recommendations for improving the transfer process.

\section{LITERATURE REVIEW}

Advocates of "articulated" postsecondary systems argue that these systems are democratizing in that they provide access to individuals with less privileged backgrounds to pursue postsecondary studies through to university degree completion (Alberta Advanced Education, 1984; Dennison \& Gallagher, 1986; Fortin, 1987). However, numerous studies conducted over the past 25 years have revealed that transfer rates from community colleges to universities have been consistently low and that the probability of degree completion is generally superior when postsecondary education is commenced in a degree-granting institution (Alba \& Lavin, 1981; Anderson, 1981, 1984; Andres \& Krahn, 1999; Astin, 1982; B.C. Council on Admissions and Transfer, 1989; B.C. Ministry of Advanced Education and Training, 1987; Bell, 1998; Clark, 1960; Medsker \& Tillery, 1971; Pascarella, Edison, Nora, Hagedorn, \& Terenzini, 1998; Velez, 1985; Whittaker \& Pascarella, 1994). Karabel (1986) demonstrated that students who were similar in terms of socioeconomic background, academic ability, educational aspirations, and other relevant individual characteristics were more likely to earn a bachelor's 
degree if they commenced their studies in four-year institutions. In a study on the distributive effects of public two-year college availability, Tinto (1975) found that the presence of a public two-year college in a community acted as a redistributive mechanism and did less to increase rates of college attendance than to alter the type of postsecondary institution attended.

Dougherty (1987) offers a model to explain how community college entrance hinders the educational attainment of baccalaureate aspirants. He describes three key processes which create a funnel-like structure to militate against transfer to degree-granting institutions and subsequent degree completion. These processes include attrition before transfer, difficulty in the transfer process, and attrition after transfer. First, attrition during the first two years of community colleges is associated with lack of residential facilities, low academic selectivity and prestige, and lower expectations of instructors. Second, difficulty in the transfer process is related to the vocational orientation of community colleges, the need to move to a new institution, and difficulty in gaining admission to and obtaining financial aid at four-year institutions. Third, attrition after transfer is associated with credit loss suffered in the transfer process, declines in grades, lack of financial aid, and problems becoming socially integratéd into the new institution. Together, Dougherty concludes, these institutional effects prevent large numbers of students who begin in community colleges from successfully attaining the goal of completing a baccalaureate degree.

Several studies document difficulties incurred at all stages of the transfer process (Alba \& Lavin, 1981; Grubb,1991; Lee \& Frank,1990; Lee, Mackie-Lewis, \& Marks, 1993; Nora \& Rendon, 1990; Prager,1993; Velez \& Javalgi,1987). Attrition after transfer has been found to be influenced by loss of credits (Dennison \& Jones, 1970; Dougherty, 1987; Small, Vaala, \& Tyler, 1989; Swift, 1986; Vaala \& Holdaway, 1989), inadequate academic performance (Diaz, 1992; Johnson, 1987; Willingham, 1985), finances, residence location, admissions policies (Cohen \& Brawer, 1981; Cross, 1968; Pascarella, 1986; Rich,1979), and problems conforming to traditional student services (Anglin, Davis, \& Mooradian, 1995). Lunneborg and Lunneborg (1976), 
and Sandeen and Goodale (1976) found that community college transfer students had a lower social and academic self-image, lower academic ability and motivation, and were half as likely to aspire to education beyond the baccalaureate degree than those students who began their postsecondary studies at the university.

\section{TRANSFER IN BRITISH COLUMBIA}

From its inception, the community college system in British Columbia has offered university-equivalent courses. In the report attributed to providing the blueprint for the British Columbia postsecondary system, Macdonald (1962) envisioned that community colleges would offer "two-year academic programmes for students who will either transfer to degree-granting institutions or will complete their formal education at this level" (p. 51). Together with lower tuition fees, flexible admission requirements, and programs located within commuting distance, community colleges in B.C. were intended to enable students from less advantaged backgrounds to pursue postsecondary studies, and if desired, transfer to university to complete degrees (Dennison \& Gallagher, 1986).

The extent to which B.C. community college students transferred successfully was monitored as early as 1968 (see, for example, Dennison \& Jones, 1968; Dennison \& Jones; 1970; B.C. Research, 1972; Dennison, 1977; Jones, Forrester, \& Dennison, 1979; Forrester, Jones, \& Dennison, 1980). Although some of these studies indicated that college students achieved slightly lower grade point averages and slightly higher attrition rates than students who began their studies at university directly, only one study (Dennison \& Jones, 1970) noted that some students had encountered problems in the transfer process - for example, loss of credit due to having taken more courses than allowed, wrong courses taken at college, and incorrect course sequences. All other studies focused on the measurable performance of students, rather than on the performance of institutions in providing optimum conditions to facilitate successful transfer, or on the experiences, successful or otherwise, of students undertaking the transfer process. 
British Columbia transfer statistics collected in the 1980s concurred with existing literature on transfer. That is, when compared with students who entered university directly from high school, students who commenced their studies at community colleges were less likely to transfer to university. In 1985, the estimated total transfer rates from British Columbia community colleges to universities ranged from $14 \%$ to $51 \%$ with a median rate of $29 \%$ (B.C. Ministry of Advanced Education and Job Training, 1987). Degree completion rates of students transferring from college to university ranged from $8 \%$ to $32 \%$ compared with degree completion rates of $29 \%$ to $56 \%$ for those students directly entering university. The B.C. Council on Admissions and Transfer (1989) reported that second year enrolment in the college and institute sector as a percentage of first year decreased to $20 \%$ in 1987 , a decrease affecting both university transfer and career programs. Between 1981 and 1987 the percentage had been stable at $22 \%$. The Ministry of Advanced Education and Job Training (1987) concluded:

on average less than one in four full-time students who begin college academic programs can expect to end up with a first degree. Looking at it another way, those who begin studies at university have twice the chance of completion as those who begin college. (p. 11)

As a result of these findings, considerable effort has been expended to improve the transfer system in B.C. since the 1980s. In 1989, the British Columbia Council on Admissions and Transfer (BCCAT) was established as a major Government initiative intended to improve access to postsecondary education. The broad mandate of BCCAT is to initiate and facilitate activities, practices, and policies that lead toward the development of a shared vision of the inter-institutional transfer of credits by students. With the goal of promoting and maintaining an efficient and effective transfer system, the key functions of BCCAT have evolved to include: (1) the maintenance of paper and web based versions of the B.C. Transfer Guide; (2) provision of support for and coordination of the Provincial Articulation Committees; (3) collaboration with the Ministry of Advanced Education, Training and Technology, the Ministry of Education, postsecondary institutions and other agencies; (4) in-house 
research and policy initiatives; and (5) support of other research efforts which contribute to the assessment and improvement of transfer practices in the province.

Despite these efforts, transfer difficulties continued to be reported both anecdotally and in research studies. Recently, two large-scale B.C. studies sought to examine student flows through the postsecondary system and document students' transfer experiences. Five questions related to intended and actual transfer were included on the 1993 follow-up survey in a longitudinal study of 1988 British Columbia high school graduates (Andres, 1995). Of the respondents, 33\% $(\mathrm{N}=618$ ) indicated that they had indeed intended to transfer from community college to university. However, only $65 \%$ of this group reported that they actually did transfer from one institution to another. Almost half indicated that during the transfer process they had experienced a loss of credit for course work completed and over one-third reported that they had experienced difficulties registering for required courses at the transfer institution. "Other" difficulties identified by a few respondents included poor counselling, adjustment between college and university, and errors encountered during the transfer process.

The same study also traced transfer and completion rates of this cohort (Andres, 1996). In total, 532 students with the requisite high school course work and sufficient grade point averages (above 2.75) to attend university began their studies in 1988-89 at a non-university (community college or university college) institution with the intention to transfer to university. Of this group, graduation rates five years later were as follows: $21 \%$ from university, $21 \%$ from community college, $5 \%$ from university college, and 4\% from a vocational/technical institute. By 1993 , $44 \%$ had not graduated from any institution. Of the 342 students with the same academic preparation who attended universities directly from high school, $61 \%$ graduated from university, less than $4 \%$ graduated from a non-university institution, and $35 \%$ had not graduated at all.

A second study was conducted by Gaylord, Ducharme, \& Associates (1996). By employing 1995 and 1996 data $(N=14,534)$ available from the B.C. college and institutes' Student Outcomes Survey, the authors investigated the extent and nature of transfer undertaken by individuals 
exiting B.C. community college and institutes and difficulties encountered in transferring credits from one institution to another. Overall, $69 \%$ of respondents continued their studies and the majority of transfers $(62 \%)$ were from a B.C. community college to a B.C. university. Only three questions on the survey instrument were specific to the issue of transfer and the transfer of credits. Of the academic students who continued their studies, $16 \%$ reported encountering difficulties with transferring credit from one institution to another. Almost $60 \%$ of this group indicated that they were unable to transfer some credits. Analyses of open-ended comments revealed several other difficulties, including courses not accepted by the receiving institution and discontent with articulation rules. This study was replicated (with a few modifications) using 1997 student outcomes data. The findings were similar to those generated from the 1995 and 1996 data (Gaylord, Ducharme, \& Associates, 1998).

These studies, along with a large body of literature and research, inform policy and practice related to transfer by providing evidence that transfer problems exist. However, since few questions on these latter studies were dedicated to the topic of transfer, the nature of the difficulties and degree to which students experience problems during the transfer process remains unclear and several research questions remain unanswered. These questions include: How do students describe their transfer experiences? How do students seek information regarding the transfer process? Why do students encounter problems in relation to transfer? Are these problems institutionally related (e.g., difficulties with course transfer) or are problems perceptual (e.g., lack of understanding about transfer credit)? In which of the three stages of transfer (before, during, or after transfer) are difficulties encountered? What institutional policies and practices facilitate successful and non-problematic transfer between institutions?

\section{PURPOSE OF THE STUDY}

Students in British Columbia are confronted with a postsecondary system that is extensive, highly diversified and - in terms of interinstitutional articulation - complex. In 1999, the British Columbia 
postsecondary system consisted of seven public universities (including the Open University), one private university, five university colleges, eleven community colleges (including the Open College), three public institutes, as well as hundreds of private colleges and trade schools. In addition, of the fourteen degree-granting institutions, at least six serve as both sending and receiving institutions. As such, it provides students with many opportunities for inter-institutional transfer. This complexity may also present challenges for students who try to navigate their way through the system.

As part of a larger endeavour to understand issues of transfer, a study involving three phases was commissioned by the British Columbia Council on Admissions and Transfer. Phase 1 entailed an investigation of university students who had completed the transfer process (Andres, Qayyum, \& Dawson, 1997). The Phase II study focused on community college students' perceptions of transfer (Andres, 1998), and Phase III documented the history of transfer policy in British Columbia (Andres \& Dawson, 1998).

This paper reports the findings of Phase I,' a qualitative study of the experiences of university students who had transferred from community college. The central focus of this study was to (1) portray students' experiences of the transfer process, (2) document difficulties and successes encountered before, during, and after transfer, (3) highlight advantages and disadvantages of transfer, and (4) offer recommendations for improving the transfer process. Since few studies have been conducted on the perceptions of students regarding the transfer process (Gray Davies \& Dickmann, 1998), this study adds to our understanding of the transfer process from students' perspectives and complements other recent survey research.

\section{SAMPLE, DATA COLLECTION, AND METHOD}

Two institutions ${ }^{2}$ were chosen as sites for this study. First, Lower Mainland Community College (LMCC) is a comprehensive community college located in the lower mainland of British Columbia. In September 1996 , the enrolment was approximately 8,700 (38\% full-time and $62 \%$ 
part-time) with $37 \%$ of students enrolled in university transfer programs, $32 \%$ in general studies, and $31 \%$ applied programs. The second institution, Lower Mainland University (LMU) is a mid-size comprehensive university. In 1996, LMU enrolled approximately 16,000 undergraduate students. These institutions are located in close geographical proximity to each other; hence, LMCC serves as a "feeder" institution to LMU. In 1995-96, approximately 1600 transfer students were admitted to LMU; of those, $25 \%$ (the largest proportion from any community college) transferred from LMCC. Because of the large number of transfer students, a close working relationship exists between the two institutions.

In January 1997, letters of invitation to participate in a study of transfer were sent to the entire population $(\mathrm{N}=394)$ of students who had transferred from LMCC to LMU in 1996. Students were also invited to share their transcripts with the researchers in order to verify the transfer of credit hours from community college to university. In total, 65 students agreed to participate by returning the consent forms. Each student was contacted by telephone to arrange a face-to-face interview. Over the course of six weeks, 47 individuals ${ }^{3}$ were interviewed (45 face-to-face and 2 by telephone interviews). Interviews were approximately $30 \mathrm{~min}-$ utes in length and were recorded on audio tape.

All interviews were transcribed. Transcriptions were read, first, to identify descriptive patterns and themes (Huberman \& Miles, 1994). A coding scheme was generated inductively and the transcriptions were reread and coded according to this scheme. Descriptive themes and patterns were clustered into conceptual groupings based on the three phases of transfer attrition advanced by Dougherty (1987). In addition, the technique of content analysis (Holsti, 1969; Krippendorf, 1980) was used to assign numerical values to the transcript data. An SPSS file was generated from the coded data and merged with institutional data.

The central purpose of the study was to describe students' experiences and perceptions of transfer. The actual substance of the interviews - that is, the words of the students - is used to highlight students' experiences and perceptions of transfer. To ensure "analytical honesty" (Miles \& Huberman, 1984), the quantified interview data are presented as percentages, where appropriate, to permit an analysis of the frequency 
of responses to a given question. The frequencies reported in this paper are intended to provide an indication of the degree to which responses were shared among interviewees. Frequencies also serve as a check against overweighting the facts. According to Miles and Huberman, "doing qualitative analysis of all the data with the aid of numbers is a good way of seeing how robust our insights are" (p. 216). In all instances, the valid percentage of responses is reported.

Since this study focused on the transfer experiences of students from one community college to one university in British Columbia, it is important to consider the extent to which these findings and recommendations are relevant to other students who have transferred from community college to university. Transferability of the findings to another setting (i.e., to transfer students at another university) depends on the "typicality of the phenomenon" (LaCompte \& Goetz, 1982; Wolcott, 1973) or degree to which the phenomenon under investigation is comparable. According to LaCompte and Goetz, the credibility of cross-site comparisons depends on four factors: selection effects, setting effects, history effects, and construct effects. Hence, transferability of the findings depends on the following: the extent to which the students selected to participate in the study are comparable to other student groups; the history of relationships between a given university as the receiving institution in relation to its sending institution(s); the milieu of the university regarding issues of transfer and student success; and the effects of geographic location.

\section{FINDINGS}

In this section, I begin by describing the demographic characteristics of the respondents and highlighting the reasons they provided for commencing studies at community college. Then, following Dougherty's (1987) model of key transfer processes, the interview data are presented around the following themes: experiences before transfer; the transfer process; and experiences after transfer. This section concludes with an analysis of students' comments on the differences between community college and university and the advantages and disadvantages of commencing studies at a community college in the quest to earn a baccalaureate degree. 


\section{Demographics and Reasons for Attending Community College}

Slightly more females (58\%) than males participated in the interviews and the majority were 20 to 22 years of age. Only four individuals in this study were over the age of 25 . Over half $(55 \%)$ of the interviewees attended LMCC directly out of high school, then transferred to LMU. The second most common trajectory involved transferring to LMU after having been out of school for a period of time. Almost all of those interviewed (94\%) reported that they had transferred from LMCC in 1996, with the remainder having transferred in 1995 . Most $(80 \%)$ interviewees were studying full-time. A small proportion attended LMCC and LMU concurrently or in various combinations of full- and part-time.

Interviewees in this study were enrolled in a wide variety of programs, including business, criminology, education, general studies, and sciences. In addition, eight other program areas were identified. Although not representative of the full range of university course offerings, participants in this study were not concentrated in one or two programs. Institutional records provided by LMU confirmed that over half $(55 \%)$ of the interviewees had obtained a university admission GPA of 3.00 or greater; $44 \%$ had earned an admission GPA of between 2.50 and 2.99. Almost all interviewees indicated that they had declared a major before transfer, and over three quarters continued with the major they had initially declared.

As reported in Table 1, respondents provided a number of reasons for commencing their postsecondary studies at a community college first, then transferring to university, rather than entering university directly. Over one-third of the interviewees described community college as a "stepping stone" to university, a way of easing out of high school before tackling the rigours of university life. The following are examples of students' comments:

Because basically I was from a small town and I didn't want to go straight into a huge university and I thought I'd start out small. That's the only reason.

When I graduated from high school, the reason I went to LMCC first is mainly because the people said the transition to 
Table 1

Main Reasons for Attending LMCC Before LMU

of cases

College as stepping stone

Cheaper cost at college

Geographically closer to home

College as second chance

(e.g., lower entrance requirements)

Refused university admission

Language requirements (TOEFL)

No previous experience in postsecondary education

university would be easier from college and secondly it's cheaper and closer to home. So there's a variety of reasons. A lot of people have said when they went to university from high school they felt really lost. They didn't feel they got a lot out of it.

Of the interviewees, $31 \%$ attributed their decision to start at a community college to the financial incentive of lower tuition rates.

Mostly because of money. That was it... a little bit the smaller classes... [to] sort of ease myself into university plus the money. It was cheaper.

A few students said that since community college was reputed to be easier, it was a good way to embark on a postsecondary career with better chances of a higher GPA. For some students, entering into university directly from high school was not an option because their secondary school marks were not good enough.

I could not get into university. So after high school the only way, the alternative path to get into university for me, is to study [at] college. Rather than retaking grade 12 course to get high grades. 
A number of respondents who were immigrants to Canada and spoke English as a second language said that they were not qualified for university admission. Community college was a way to get started on their postsecondary education until such time as they passed the Test of English as a Foreign Language (TOEFL).

\section{Experiences Before Transfer}

As outlined in the review of the literature, students may encounter several barriers to transfer. This section documents interviewees' experiences before the actual transfer had taken place. These experiences include the following: timing of intent to transfer, resources students used to facilitate the transfer process, difficulties with accessing and using resources, and experiences with advisors and counsellors at LMCC and LMU.

For the vast majority (85\%) of interviewees, transfer to university was premeditated early in their postsecondary careers, and LMU was most frequently identified as the target university in mind. Most students knew exactly what program they wanted to enter from the beginning; that is, they intended to transfer either before or from the outset of attending LMCC. A few others had changed their minds along the way.

My whole original plan was to transfer from LMCC [to LMU]... I started with that intention.

I knew I wanted to attend LMU to finish my degree so I got as many credits as I thought I could at LMCC, and then I just had to get a transcript and actually apply.

I wasn't sure if I was going to transfer to LMU, but I knew I was going to transfer to university. When I chose my major which is criminology, I decided to transfer to LMU or [another B.C. university].

Only one individual decided to transfer after having completed studies at LMCC.

Since most respondents attended community college with the intention to transfer, they described planning their college course schedule accordingly. Almost all (97\%) interview participants claimed that they 
were usually very attentive to the question of transferability, and were careful to take courses that they knew were transferable to university.

I would go by what courses I can transfer so I wasn't losing any credit hours or money.

I wasn't quite sure what I wanted to focus on, what major or minor. So all I did was ensure that the courses that I did take were all transferable. I took like a wide range of courses and they were all transferable... All I knew is that they were transferable and that I knew I needed 60.

I pretty much took courses that I knew would transfer for the most part... I didn't want to waste my time taking courses that didn't transfer.

However, $20 \%$ of interviewees indicated that they also enrolled in courses out of interest or to fulfill the requirements for a program at LMCC. Only three individuals indicated that their course selection was haphazard and not at all guided by transfer requirements.

Interviewees were asked to indicate all of the resources they used to assist them with the transfer process. Community college and university calendars were the most commonly used resources, followed by academic advisors at LMCC. LMU advisors were used somewhat less often. Most interviewees (66\%) reported using three or more resources to help them with the transfer process. Only two individuals claimed that they did not use any resources at all. The detailed B.C. Transfer Guide produced by the British Columbia Council on Admission and Transfer was not a commonly used resource; most of the interviewees did not know of its existence. However, the 12 individuals who referred to it found the Guide to be useful. Only three respondents indicated that the B.C. Transfer Guide was confusing or inaccurate.

Of the interviewees, $32 \%$ claimed that they had difficulty using the available resources.

I find it frustrating... reading the calendar... It's so confusing. The rules and the details. What course and what course counts as what requirement, what category of requirement.

[At] some point I got very confused. 
You have to get a transcript of your grades and courses and then you have to check the transfer guide and it has a big listing of all the colleges and what they transfer... That was a big hassle because some of the courses I couldn't find... I was like "does it transfer or not?" I was worried. It just said "business" and that's it. Then I found out later it's just a business credit.

Before transfer, the majority of interviewees consulted only with a LMCC advisor. Only $13 \%$ indicated that they had consulted with a LMCC and LMU counsellor before and during the transfer process, and an additional $18 \%$ indicated that they had sought the assistance of a LMCC advisor before transfer, and an LMU advisor after transfer. Approximately equal proportions of students reported positive and negative experiences with LMCC counsellors and advisors. Although LMU advisors and counsellors were not consulted as often as their counterparts at LMCC, students were more likely to report positive experiences with the university advisors. Advisors and counsellors who provided information verbally about what courses to take, distributed handouts about exact courses needed for specific programs, and imparted information about where to look in calendars and transfer guides, were identified by students as helpful. The following comment provides an illustration of a positive experience:

Everyone was helpful at LMCC and LMU. I got the information that I wanted. I actually made an appointment at LMU. That was when I got my application package. So [the advisor] explained a lot to me. She was helpful. She could of been a little more helpful. I was applying for a scholarship and there was some information she neglected to give me and that was information I needed... LMCC pretty much answered all my questions.

The counselling experience was described as negative if advisors and counsellors provided information that was incorrect, out of date, overwhelming, or inconsistent. For these students, talking to academic advisors at LMCC was not useful.

[LMCC counsellors] knew a bit here and there. But certain questions... the counsellors didn't know very much... and 
then they would go, "Well you should go up to LMU and ask." Every time I came up here it's like nobody would pay attention to you.

You're running around. It becomes frustrating and a waste of time. You get nothing accomplished. And then half the time when you do get something answered it's not answered directly. That becomes very frustrating. I've had that happen more than once... I'm upgrading a course due to misadvice. I'm sick of it.

No information, not enough information, and unavailability of advisors were also deemed to contribute to a negative experience.

\section{The Transfer Process}

The research literature identifies several obstacles to successful transfer during the second or "transfer process" stage. In this section, I focus on two potential obstacles: gaining admission to the receiving institution and the transferability of credits.

The majority $(70 \%)$ of students described the transfer process as rather straightforward, simply a matter of reading the LMCC calendar and adhering to what the available information indicated was transferable and what was not.

In terms of the transfer, it was just a smooth sort of process. It wasn't a big deal or hassle.

It's been really smooth for me... It's been so easy... I applied to come here. I got my courses transferred, no problem.

However one-third of interviewees described the transfer experience as very complicated and confusing. The available information was insufficiently clear; it was hard to work out an acceptable program of studies that satisfied the necessary transfer requirements; it was difficult to determine whether the information was current, to understand what it meant, or what aspects of it were most pertinent. Yet on the whole, despite the different levels of complication identified with regard to getting the necessary transfer information from the various sources available, most students $(71 \%)$ satisfactorily transferred most or all of the credit hours earned at the community college. If they had taken 
courses for which transfer credit was not a possibility, they usually knew it at the time. Almost half of respondents indicated that at least one of their courses was not transferable. Half of those who transferred fewer than 60 credits and $53 \%$ of those who transferred a full 60 credits reported that some of the credits earned at LMCC were not transferable to LMU.

Of the respondents, $30 \%$ pointed out several difficulties with the admission process. Most frequently cited were repeated attempts required to gain admission, TOEFL scores that did not meet the minimum admission standard, low grade point averages, insufficient transfer credit, and transcript delivery problems. As one student remarked,

I had to do an extra semester before I came up here 'cause... right before I was going to put in my application I found out there was a course I had to take so that put everything off by another... semester... I had planned to come for the fall. So I had to put everything off 'til January.

For the majority of the students interviewed, although the mechanics of the transfer process did not present an overwhelming source of distress, several sources of concern were raised. Some students identified problems associated with the transfer mechanism, that from their perspective, involved mistakes - or at least miscuing - on the part of one or the other of the institutions involved. This was often described as miscommunication between LMCC and LMU. One aspect of misapprehension involved the difficulties which some students experienced in attempting to make sense of the information available to them regarding how to go about transferring from one institution to another.

We had been told by the head guy in the PE Department that it doesn't matter where you go, it's all going to be the same. So you get that assumption that it doesn't matter what course you take, they're all going to transfer... I probably took my two years worth at LMCC so I assumed that was basically going to be finished my two years of PE so I could come here and do, like third level, right, or 300 level or whatever. And I got here, and I have to do other ones... it seems like some of them are similar to the ones at LMCC, but they're not.... exactly the 
same. So they, you don't give me the credit for it. So it's really.... bad. I... was really disappointed. It's a set-back.

There were also a number of problems that revolved around confusion about the required procedures. Students claimed that there was considerable lack of clarity around the weighting of credits, and bestowing "unassigned credits" in some transfer situations (transfer of courses, but not transfer of credits - referred to by students as "triple zeros").

I had taken one business and one math [course] that weren't transferable specifically but they were credits towards business, or towards math and they transfer those as [triple zeros].

I took this psych. course which is a 200 level and it's only a 100 level here [at LMU]... Sometimes you take a 300 level course here and when you transfer it here, it's a 200 level course. So it wouldn't count as an upper division.

Also, it was a revelation that transfer involved a two-step procedure - acceptance into the institution, then acceptance into a specific program. As one student remarked:

I never understood that... I applied to LMU wanting to be a criminology student but now I got into the school, but my GPA is not good enough to get into the criminology program. And I don't know. It was never set out for me... And now I don't know what to do. I'm panicking now.

For most students, misunderstandings about the transfer process were annoying. Others were angry about the associated financial and temporal loss. One interviewee remarked that in her attempt to transfer "a lot of little things...drove me insane."

\section{Experiences After Transfer}

The body of research on transfer indicates that transfer problems do not end after the act of transferring is completed. Two potential problems identified by Dougherty (1987) - a decline in grades after transfer and difficult integration into the receiving institution - are featured in this section of the paper.

Of all the issues associated with transfer, the decline in grade point average (GPA) after transfer was the most significant and the one that 
consistently caused students the most anxiety. Only 5 of the 47 students interviewed reported an increase in grades following their transfer from college to university. These students claimed their grades improved because they were more interested in the course material and were responding positively to the more challenging academic environment of the university. A few students claimed that their grades had remained about the same. However, by far the majority of respondents reported that their GPA had gone down at university, and that in association with the decline in their grades, they had found the move from college to university difficult and stressful, sometimes to the point where they felt they had encountered a serious setback in achieving their academic goals. A few students reported being on "academic probation" because their grades had dropped to a level of marginal acceptability. Examples of students' comments accentuate all three scenarios related to grades after transfer:

[My grades] went down. It was horrible.

I would say [my grades are] similar. A lot of people were telling me actually to expect them to be a little more difficult here at LMU. And in all sincerity, I don't find that at all.

[My grades are] a little higher because you have to work a little harder. You want to finish your degree... you want to get a good mark. You don't want to be the bottom half. Try and be on the top.

The main reasons provided by interviewees for declines in grades are summarized in Table 2 under the following headings: general institutional, classroom, course content, individual, and professors/teaching assistants. Four factors - increased academic rigour, the grading system (in particular the perception that the bell curve grading system was used), larger classes, and limited contact with instructors at LMU - were most frequently implicated as being responsible for declining grades. Respondents' comments highlight the findings summarized in Table 2:

I freaked out. My first semester was so tough. It was such an extreme from college.

It's definitely because of the curve and it's the type of students you're dealing with when you come up here... It's a very serious school up here. You can tell just from the atmosphere. 
Table 2

\section{Main Reasons for Post-transfer Decline in GPA}

General Institutional

Marking system at LMU (i.e., the bell curve) 43

LMU more academically demanding 36

Student quality better/competitive $\quad 21$

Acclimatization to a large institution $\quad 11$

Classroom

Larger classes

Less class time ( $1 \mathrm{hr}$. less per needed course)

Less individualized attention

\section{Course Content}

More difficult/heavier course work at LMU

Exams/papers harder

\section{Individual}

Did not work as hard at LMU as at LMCC 7

Lack of focus by student $?$

Taking too many courses $\quad 4$

Professors/TAs

Limited contact with actual instructor at LMU 29

Difficulties with TAs

At the classroom level, students most frequently attributed lower GPAs to large classes and decreased class time. Course content was deemed by $29 \%$ of interviewees to be more challenging. Also, examinations were considered more difficult and course assignments were described as more abstract. 
I had more hands on experience at LMCC I found... So [now] there's a lot more theory involved."

You have to do a lot more work at university. You have to study more. It's harder... I think they expect more of you. You have to read more. The tests are harder. I think they mark the papers harder too.

The expectation is a bit higher here at LMU. For the exams, the midterms and the finals are definitely harder... Harder, in several senses is, because the lecture room is so big you're not likely to ask a question if you have some problem understanding the material. The prof usually wants to cover a specific amount of material in that time and so you don't sense they want to stop and answer your question. So that factor plus the big class, you don't really want to stop the class either so in that sense you're not listening and concentrating as much... I say for me it was poor. Poorer.

A few individuals directed the responsibility for lower achievement after transfer at themselves. As one student commented: "I [ $\mathrm{m}]$ lazy and I'm not very used to the way they teach." As illustrated by the following comments, whereas some students associated limited or unsatisfactory contact with professors and teaching assistants with a drop in grades, others pointed out differences in expectations held by LMCC and LMU faculty:

I don't think the professors bring much of their personal experience into it... Profs work the book. A lot of that.

At LMCC the teachers are more approachable, the profs. here, I find are over-educated. I wouldn't want to ask them something because I'd feel like an idiot.

[LMU professors] just expect a lot more. As far as the course work, it's pretty much the same but when it comes down to the nitty gritty on the test, they're a lot harder and the professors expect you to do the work on your own. They are available for help but, at LMCC it's almost like high school. The work is the same but it doesn't prepare you to do the work on your own because they hold your hand down there. Up here you gotta do it yourself. 
Some students reported that they had since acquired skills and strategies to adapt to the teaching and learning experience offered by the university, including visiting an advisor at LMU, learning how "it works" at LMU, then devising strategies for studying and coping with a bigger workload, improving their study habits, and reducing their course load. For some students, the result was an increased GPA. Students who reported that their grades had actually increased after transfer indicated that they had worked harder right from the beginning, changed their attitude upon admission to the university, and were driven by wanting to earn good grades to get into a specific program.

I'm taking only three courses this semester so I could boost [my GPA].

[My GPA] is going up a bit now that l'm getting used to it. It was a really big switch though because I was used to the way I studied at LMCC. And it worked for me so now I had to change it all. My grades are going back up, I just had to get used to the new way of studying and bigger work load.

You have to work a little harder... The higher the GPA the better the chance you have.

Although some students claimed that the greater challenge associated with university caused them to learn more, others said that they learned less because they did not have the opportunity for discussion that helped them learn. One student commented that the university climate was one that promoted "grade thirst" at the expense of "knowledge hunger".

The interview respondents presented a number of different interpretations of the difference between college and university to account for the decline in grades that they experienced. Many of them described college as being smaller, friendlier, and more supportive than university.

I prefer the smaller classroom setting and the style at LMCC... You get more individual attention here and they seem to encourage discussion more during class.

Of the participants, 29\% described LMU as being big, confusing, cold, or impersonal, where it was hard to make friends and to penetrate the prevailing "nobody cares" attitude. 
It's so big [at LMU]... Coming here was vast, you know. This huge concrete everywhere and all these faceless students and nobody even looks at you or smiles at you. You know, everybody's in a rush and it was just overwhelming.

Academically, they said that LMU was a much harder and more challenging learning environment, the amount of work was more extreme, the guidelines were less clear, and much more independent work and initiative were expected of them. Several students $(30 \%)$ claimed that the smaller, friendlier atmosphere at LMCC meant that instructors were more approachable and accessible, it was easier to speak out in class, and that there were more opportunities for discussion and clarification of course material.

I find the people who come from college, their participation is higher because we were really encouraged to talk during courses. And a lot of people at the university level are afraid to speak out. A lot of the early courses, the 100 level courses, are very big so you don't get a chance to talk so I don't think they're used to that.

Some were very critical of the attitudes of university professors relative to college instructors. Professors were occasionally perceived to be distant, inaccessible, and bound by fewer expectations to be clear and communicative. However, some students claimed that college was too much like high school, that there was too much "spoon-feeding," and that because it was easier to know what was going to be on the exam, one could memorize just enough to get by and then forget it.

Most interviewees maintained that despite the annoyances related to the transfer process and a declining grade point average after transfer, in the long run, transferring from community college to university was the preferred route. Community college was described by $40 \%$ of interviewees as having provided solid preparation that eased the transition to university. This ease of transition was reported most often as the major advantage of transfer.

I think that the advantage was that it's more of a learning step coming from college to university. You get a little more adjusted rather than an initial whack in the head. 
Other advantages included tuition fees that were less financially taxing, the intimacy of a smaller institution, the opportunity to improve one's GPA, and small class size.

Only a handful of students were dissatisfied with their chosen educational trajectory. Some would have preferred to complete the requirements for their degree within the confines of the small, intimate climate afforded by the community college. A few others felt that they should have delayed transfer to LMU. A small minority (10\%) claimed there was little difference between the two institutions.

There wasn't much of a difference in going to classes there so plus the teaching styles are basically the same. Except in English they're different. Didn't make much of a difference. You just couldn't get a degree in colleges.

The key disadvantages involved adapting to the teaching, learning and studying styles at two different institutions and the extra demands placed on transfer students that were not expected of students who commenced their studies at university. These demands included being aware of the transfer process, enroling in courses that were transferable, and spending considerable amounts of time on complicated processes and procedures related to transfer.

You have to adjust again once you get to a place. You're put in another situation where you have to learn the whole system again.

You have to spend time in those courses which are transferable. But for the university students they don't have to spend time thinking about that about those courses that can transfer to other institution. To spend much time talking with someone, thinking about it, what can transfer.

Of course you tend to be a bit of a mutt. You never connect in the same way... The problem is that you don't have a clean package.

Finally, one additional finding warrants comment. As reported earlier, several students described the transfer process as "a breeze." In fact, eight individuals $(17 \%)$ reported that they did not have difficulties with any of the following: gaining admission to LMU, transferring courses, or 
registering for classes at LMU. Only three individuals claimed to have difficulty with all of these dimensions of transfer and the remaining $78 \%$ experienced difficulties with one or two of these dimensions. However, regardless of the degree of difficulty encountered by individuals, there was an overriding sentiment that most students were bewildered by some aspects of the transfer process. The following comments indicate that for most students, transfer is a mystifying process.

I know [LMU] left off some of my better grades and took some of the lower grades... I had no say, like, you know I just gave them my transcript and when they got back to me about getting into the school, they showed me what courses got transferred.

I had to get my transcripts done and the transfers were hard to understand. I just thought they were your grades on your report card. I had to go back and forth so many times until I understood what transcripts were. They were official documents that had to be sent. That was confusing.

Students' comments support the findings of Gaylord et al. (1996). An analysis of open ended comments on a survey of community college and institutes' questionnaire led these authors to conclude that "students generally appeared to have only a limited grasp of 'the big picture' and their comments often betrayed their confusion" (p. 19).

\section{DISCUSSION}

The purpose of this study was to provide an in depth account of the phenomenon of transfer by focusing on the experiences of students who transferred from community college to university. Whereas previous survey research has provided considerable information about the types of difficulties experienced by students, the study reported in this paper attempts to look beyond the numbers to provide a more detailed account of the transfer phenomenon from the perspectives of the students. As such, the experiences of the participants provide a depth of insight that cannot be easily attained by other methods of inquiry.

The highly diversified and relatively autonomous nature of the B.C. higher education system provides several routes to degree completion. 
However, the complexity of such a system can also create problems and obstacles for the student intending to transfer. As Finlay (1997) asserts, "a significant challenge for the B.C. postsecondary system has always been to maintain choice and diversity in degrees while balancing the needs of students to transfer smoothly between and among the member institutions" (p. 6).

It is noteworthy that several of the findings of this study are similar to those reported in other U.S. and Canadian studies on transfer in articulated postsecondary systems. Specifically, in a study carried out at the Colorado State University of in 1996, Gray Davies and Dickmann (1998) reported that students did not use the Colorado equivalent of the B.C. Transfer Guide to inform their transfer decisions. LMU students' comments regarding declining grades after transfer to university echoed those of a smaller scale U.S. study reported by Townsend (1995). Most LMU students indicated that obtaining transfer credit was not a significant problem area; this finding concurs with those of a study conducted ten years earlier in Alberta (Tyler \& Small, 1990). However, the finding that over three quarters of LMU students reported difficulties with one or two dimensions of the transfer process is similar to figures reported by Andres (1995) and Vaala and Holdaway (1989). Similarities in results across different jurisdictions, but within the context of community college to university transfer, suggest that on some dimensions transfer students share common experiences and problems.

Transfer students are disadvantaged in that they are required to negotiate an additional hurdle in pursuit of their ultimate educational goals. The findings of this study indicate that problems do occur at each of the three stages of transfer as specified by Dougherty (1987). Key among these obstacles to successful transfer by students are: (1) difficulty gaining access to useful information; (2) difficulty understanding transfer policies, practices, and procedures; and (3) declines in GPA following transfer to university. Although the majority of students in this study support transfer as a viable and even preferable route to university degree completion, the findings suggest that the likelihood of successful transfer could be enhanced through improvements to existing transfer policies and practices. 
First, to facilitate efficient and effective transfer, students must know how to gain access to information about the transferability of credits, the rules and regulations of transfer, admission requirements, and other available resources. All agencies involved in the transfer process, including the B.C. Council on Admissions and Transfer, sending and receiving institutions, secondary and postsecondary advisors and counsellors, and postsecondary faculty have a role in ensuring that students can gain access to and understand the information they need. This study demonstrated that few students are aware of or made use of resources such as the B.C. Transfer Guide. In response to the findings of this study, the B.C. Council on Admissions and Transfer has recently published a document entitled B.C. Transfer TIPS: Transfer Information for postsecondary Success (B.C. Council on Admissions \& Transfer, 1999). This handbook is intended to provide information about the mechanisms and process of transfer to students in a clear, unambiguous, easily understandable manner. This student-oriented handbook, which complements the information available in other resources such as the B.C. Transfer Guide and institutional calendars, is a positive step toward empowering students with the information they need to reach their educational goals.

However, written documentation does not replace the need for knowledgeable postsecondary personnel to assist in the interpretation of transfer policies and practices. Previous research suggests that the transfer student is often not the preferred student and is ignored regarding orientation, advising, and other student services (Sandeen \& Goodale, 1976). Advisors at both sending and receiving institutions serve as key information brokers in ensuring that students receive accurate information. Flexible hours of operation, regular group advising sessions devoted to transfer issues, orientation sessions at receiving institutions, and perhaps even mandatory advising sessions at sending institutions for all students intending to transfer may help to reduce the amount of confusion and frustration experienced by students. As Cohen (1997) points out, "navigating a chaotic system... does not happen automatically but as a function of college activities and the perceptions held by students and staff members" (p. 34). 
Advising should not be limited to personnel within postsecondary system. Current and prospective secondary school teachers and counsellors have a significant role to play in guiding students through the transition from high school. They are critical "gatekeepers" who (should) possess key information about the types and roles of various postsecondary institutions, including different routes through the system. Topics related to postsecondary education in general and transfer in particular should be incorporated into the curricula of teacher education and professional development programs.

It cannot be assumed, however, that institutional personnel necessarily have the requisite knowledge about the intricacies of transfer. In the Report of the Task Force on Standards and Processes (1997), the authors point out that:

students are not the only ones who are confused. The complexity and inconsistency of transfer arrangements and degree requirements between postsecondary institutions can create confusion and misunderstanding even among faculty, advisors, and educational administrators (p. 10).

Dissemination of general information about transfer and regular updates to changes in transfer policies and practices will ensure that those responsible for advising students remain current with system processes and requirements.

In articulated systems of higher education, extensive coordination is an essential component of efficient and effective transfer processes. According to the Report of the Task Force on Standards and Processes (1997),

students should not be disadvantaged as a result of the administrative processes in place at their institutions or at the institutions to which they wish to transfer... Institutional practices which are consistent across the system may provide a more equitable environment for students seeking to transfer. (p. 2)

Students, as active agents in their own lives, will probably always be responsible for their survival in and through the system. I agree with Graham and Caplow Hughes (1994) that "transfer students need to understand that the campus and student cultures will be different and develop different skills necessary to enhance their success" (p. 461). However, the 
postsecondary system, through its formal structures, policies and practices, can contribute significantly to successful transfer by students. Coordination activities are critical to the overall health of the transfer system. The primary purpose of the B.C. Council on Admissions and Transfer is to initiate and facilitate activities, practices and policies that lead toward the development of a shared vision of the inter-institutional transfer of credits by students. However, as pointed out by Finlay (1997), articulation in B.C. is voluntary process which depends on trust and agreement among individuals representing autonomous institutions. Ongoing coordination efforts to streamline the transfer process - such as block transfer and prior learning assessment - require active participation by the provincial articulation committees, the Ministry of Education, the Ministry of Advanced Education, Training and Technology, and representatives from postsecondary institutions.

The after transfer experience also falls under the rubric of interinstitutional coordination. Although numerous studies report that the grade point averages of transfer students increase gradually after the first semester at university, several authors (Dougherty, 1992; Graham, 1987; Graham \& Dallam, 1986) suggest that this increase may be due to after transfer attrition by higher numbers of low achieving students. As a result, the overall GPAs of the remaining students provide a distorted picture of academic achievement of transfer students.

Rather than following Graham and Dallam's (1986) suggestion that to provide a realistic indication of post-transfer achievement, students should adjust their GPAs downward by two- to nine-tenths of a point, more positive initiatives related to teaching and learning should be encouraged. Ongoing dialogue and articulation of teaching and learning practices at both sending and receiving institutions could facilitate a smooth transition from community college to university. For instance, incorporation of effective teaching strategies for large classrooms as highlighted by Gilbert (1995) and efforts designed to raise instructors' awareness of teaching and learning problems encountered by transfer students at both community colleges and universities may help to mitigate the magnitude of "transfer shock" experienced by students. 
As stated at the beginning of this paper, fully articulated transfer systems exist in only three Canadian provinces. Other provinces have adopted varying degrees of inter-institutional transfer arrangements (for example, see Bell, 1998). The general trend toward promoting seamless routes through the postsecondary system will be influenced by the history, culture and traditions of each provincial system. For example, according to the Ontario Report of the Advisory Panel on Future Directions for Postsecondary Education (1996),

it is through the continued emergence of differing strengths among colleges and universities that the multiple purposes of postsecondary education can be best attained. Given the potential for continued differentiation and the proven value of the distinct mandates of each category of institution, the Panel believes that the basic idea of parallel systems of colleges and universities is still sound and necessary. (p. 41)

Regardless of the degree to which inter-institutional transfer is embraced by each provincial system, the key recommendations of this study improving access to useful information by students; facilitating transfer through extensive coordination of transfer policies, practices, and procedures; and addressing differences in the teaching and learning experience at sending and receiving institutions - are relevant to any system in which numerous routes through the postsecondary system are available.

This study was delimited to the experiences of students who transferred successfully from one institution to another and does not describe the experiences of those who were unable to negotiate such a transition. Issues of access and equitable opportunities for university degree completion must remain central in ongoing research about transfer. From the outset, the transfer function at B.C. community colleges was intended to enable those from less privileged backgrounds or those without easy access to urban universities to pursue university degree completion by offering university-equivalent courses. In terms of overall life chances, however, critics have long alleged that attendance at a community college is far from democratizing (Brint \& Karabel, 1989; Karabel, 1986; Pincus, 1986). Students from lower socio-economic status, women, ethnic minorities, and those with lower achievement levels in high school 
may be more likely to experience difficulties with transfer (Andres \& Krahn, 1999; Grubb, 1991; Lee \& Frank, 1990; Lee, Mackie-Lewis, \& Marks, 1993; Nora \& Rendon, 1991; Prager, 1993; Townsend, McNerney, \& Arnold, 1993; Velez \& Javalgi, 1987). According to Dougherty (1992), given the overwhelming evidence in numerous research studies that even after controlling for students' educational backgrounds, abilities, and aspirations, "defenders of the community college must face the fact that these differences in student characteristics do not entirely explain the baccalaureate gap" (p. 190).

Recent findings in the life course literature indicate that in recent years, individual life trajectories have become "destandardized" (Kohli, 1986), "disordered" (Rindfuss, Swicegood, \& Rosenfeld, 1987), and individualized (Beck, 1992). According to Furlong and Cartmel (1997), in the past young people boarded "trains" defined by one's social class, gender, and educational attainment that carried them to pre-defined educational and occupational destinations. Once on board, there were few opportunities change trains or tracks. Furlong and Cartmel argue that today the metaphor of a car is more appropriate. That is, young people believe they are in command of their own destinies by "choosing" from a multitude of paths and routes. Ironically, increased options within postsecondary systems may result in increased opportunities for diversion away from one's educational goals by helping "to obscure the extent to which existing patterns of inequality are simply being reproduced in different ways" (Furlong \& Cartmel, 1997, p. 7). As the paths through postsecondary institutions become more diverse and decisions regarding these routes become more individualized, vigilant monitoring of student flows - by social class, gender, and race/ethnicity - is essential. The ease of transfer from community college to university, together with other issues affecting access such as tuition fee increases and proposed changes to student financial assistance, may have an enormous impact on the criteria and conditions of access by determining what it means to "have a chance" (see Burbules, Lord \& Sherman, 1982) to participate in and complete university studies. 


\section{Notes}

1 The analyses are based on the findings reported in Andres, Qayyum, \& Dawson (1997). The author wishes to thank the co-authors for their contributions to Phase I of the Investigating Transfer Project.

2 The names of the institutions have been replaced by pseudonyms.

3 Although an additional 18 individuals completed consent forms, the researchers were unable to contact them. Problems included incorrect phone numbers, unanswered pagers and telephone messages, and missed interview appointments. The extent of representativeness was determined by comparing various characteristics of the interviewees in this study with the total body of individuals who had transferred from LMCC to LMU in 1996. When compared with the full cohort of 394, the interview sample was biased towards women, younger students, and those with higher admission grade point averages (see Andres, Qayyum, \& Dawson, 1997 for a detailed description).

\section{References}

Alba, R.D., \& Lavin, D.E. (1981). Community colleges and tracking in higher education. Sociology of Education, 54(4), 223-237.

Alberta Advanced Education. (1984). Participation patterns study. Report of the committee to examine participation trends of Alberta postsecondary students. Edmonton: Alberta Advanced Education, Planning Secretariat.

Anderson, K.L. (1981). Post-high school experiences and college attrition. Sociology of Education, 54(1), 1-15.

Anderson, K.L. (1984). Institutional differences in college effects. Boca Raton, FL: Florida Atlantic University. (ERIC Document Service No. ED 256204 ).

Andres, L. (1995). Class of 1988 grade 12 follow-up. Five years later. Report prepared for the B.C. Council on Admissions and Transfer.

Andres, L. (1996). Educational paths of the class of '88. B.C. Council on Admissions and Transfer Special Report. April.

Andres, L. (1998). Investigating transfer. Phase II. Community college students' perceptions of transfer: The case of Douglas College. Research report prepared for the B.C. Council on Admissions and Transfer.

Andres, L., \& Dawson, J. (1998). Investigating transfer. Phase III: A history of transfer policy and practice in British Columbia. Research report for the British Columbia Council on Admissions and Transfer. 
Andres, L., \& Krahn, H. (1999). Youth pathways in articulated postsecondary systems: Enrolment and completion patterns of urban young women and men. Canadian Journal of Higher Education, 19(1), 47-82.

Andres, L., Qayyum, A., \& Dawson, J. (1997). Investigating transfer. Phase 1: Transfer experiences of students from community college to university. Research report prepared for the B.C. Council on Admissions and Transfer.

Anglin, L.W., Davis, J.W., \& Mooradian, P.W. (1995). Do transfer students graduate? A comparative study of transfer students and native university students. Community College Journal of Research and Practice, 19(4), 321-330.

Astin, A. (1982). Minorities in American higher education. San Francisco, CA: Jossey-Bass.

Beck, U. (1992). Risk society. Towards a new modernity (M. Ritter, Trans.). London: Sage Publications. (Original work published in 1986).

Bell, S. (1998). College transfer students: A Canadian case. Community College Journal of Research and Practice, 22(1), 21-28.

Brint, S., \& Karabel, J. (1989). The diverted dream. Community colleges and the promise of educational opportunity in America, 1900-1985. New York, NY: Oxford University Press.

British Columbia Council on Admissions and Transfer. (1989). Some enrolment and transfer trends for non-vocational postsecondary students. Report prepared for the initial meeting of the B.C. Council on Admissions and Transfer, August 1989.

British Columbia Council on Admissions and Transfer. (1999). B.C. Transfer TIPS: Transfer information for postsecondary success. Vancouver, BC: BCCAT.

British Columbia Ministry of Advanced Education and Training (1987). Access, completion and transition to work: Completion, transfer and retention. Paper No. 8, November 10, 1987.

British Columbia Research. (1972). Performance of college transfer students at UBC, 1971-1972. Vancouver, BC: B.C. Research.

Burbules, N.C., Lord, B.T., \& Sherman, A.L. (1982). Equity, equal opportunity, and education. Educational Evaluation and Policy Analysis, 4(2), 169-187.

Clark, B. (1960). The 'cooling-out' function in higher education. In A.H. Halsey, J. Floud, \& C.A. Anderson (Eds.), Education, economy, and society (pp. 513-523). New York, NY: The Free Press. 
Cohen, A. (1997). Orderly thinking about a chaotic system. In T. Rifkin (Ed.), Transfer and articulation: Improving policies to meet new needs (pp. 25-34). San Francisco, CA: Jossey-Bass.

Cohen, A.M., \& Brawer, F.B. (1981). The persistent issues. Community and Junior College Journal, 54(4), 17-21.

Cross, K.P. (1968). The junior college students: A research description. Princeton, NJ: Educational Testing Service.

Dennison, J. (1977). Report \#26: British Columbia colleges articulation study: University-transfer programs in the community college, a 1977 perspective. B.C. Research, November, 1977.

Dennison, J.B., \& Gallagher, P. (1986). Canada's community colleges. A critical analysis. Vancouver, BC: University of British Columbia Press.

Dennison, J., \& Jones, G. (1968). A study of the characteristics and subsequent performance of Vancouver City College students who transferred to the University of British Columbia in September, 1967. Unpublished report.

Dennison, J., \& Jones, G. (1970). A long range study of the subsequent performance and degree attainment of students who transferred from Vancouver City College to the University of British Columbia from 1966-1969. Division of Research and Institutional Development, Vancouver City College, January, 1970.

Denzin, N., \& Lincoln, Y. (Eds.). (1994). Handbook of qualitative research. Thousand Oaks, CA: Sage Publications, Inc.

Diaz, P.E. (1992). Effects of transfer on academic performance of community college students at the four-year institution. Community/Junior College Quarterly of Research and Practice, 16(3), 279-291.

Dougherty, K.J. (1987). The effects of community colleges: Aid or hindrance to socio-economic attainment? Sociology of Education, 60(2), 86-103.

Dougherty, K.J. (1992). Community colleges and baccalaureate attainment. Journal of Higher Education, 63(2), 188-208.

Eaton, J.S. (1991). Encouraging transfer: The impact on community colleges. Educational Record, 72(2), 34-38.

Finlay, F. (1997). The Block Transfer Project. Consultation and Response. Vancouver, BC: BCCAT.

Forrester, G., Jones, G., \& Dennison, J. (1980). Report \#39. British Columbia colleges articulation study: University degree completion of college transfer students (University of British Columbia 1973-1979). Prepared for the Academic Council, Victoria, BC, by B.C. Research, November 1980. 
Fortin, M. (1987) Accessibility to and participation in the postsecondary education system in Canada. Saskatoon, SK: National Forum on Postsecondary Education.

Furlong, A., \& Cartmel, F. (1997). Young people and social change: Individualization and risk in late modernity. Buckingham: Open University Press.

Gaylord, Ducharme, \& Associates. (1996). Student transfer issues revealed in British Columbia's postsecondary education student outcomes surveys: An analysis intended to enhance the survey's future utility. Vancouver, BC: B.C. Council on Admissions and Transfer.

Gaylord, Ducharme, \& Associates. (1998). An assessment of British Columbia's postsecondary education transfer issues: The student perspective. Vancouver, BC: B.C. Council on Admissions and Transfer.

Gilbert, S. (1995). Quality education: Does class size matter? CSSHE Professional File, 14, 1-6.

Gray Davies, T., \& Dickmann, E.M. (1998). Student voices in the transfer process: do we hear them? Do we listen? Community College Journal of Research and Practice. 22(5), 541-557.

Graham, S. (1987). Persistence and the relationship to academic performance measures: A longitudinal study. Community College Quarterly of Research and Practice, 1I(2), 75-84.

Graham, S., \& Dallam, J. (1986). Academic probation as a measure of performance: Contrasting transfer students to native students. Community/ Junior College Quarterly of Research and Practice, 10(1), 23-24.

Graham, S., \& Caplow Hughes, J. (1994). Moving down the road: Community college students' academic performance at the university. Community College Journal of Research and Practice, 18(5), 449-464.

Grubb, W.N. (1991). The decline of community college transfer rates. Journal of Higher Education, 62(2), 194-221.

Holsti, O.R. (1969). Content analysis for the social sciences and the humanities. Reading, MA: Addison-Wesley.

Huberman, A.M., \& Miles, M.B. (1994). Data management and analysis methods. In N. Denzin \& Y. Lincoln (Eds.), Handbook of qualitative research (pp. 428-444). Thousand Oaks, CA: Sage Publications, Inc.

Johnson, N.T. (1987). Academic factors that affect transfer student persistence. Journal of College Student Personnel, 28(4), 323-329.

Jones, G., Forrester, G.C., \& Dennison, J. (1979). Report \#32-A: A comparable study of college and university students: After the second academic year. A summary. B.C. Research, June, 1979. 
Karabel, J. (1986). Community colleges and social stratification in the 1980s. In L.S. Zwerling (Ed.), The community college and its critics. New Directions for Community Colleges, 54(2), 13-30. San Francisco, CA: Jossey-Bass.

Kohli, M. (1986). Social organization and subjective construction of the life course. In A.B. Sørenson, F.E. Weinert, \& L.R. Sherrod (Eds.), Human development and the life course. Multidisciplinary perspectives (pp. 271-292). Hillsdale, NJ: Lawrence Erlbaum.

Krippendorf, K. (1980). Content analysis. An introduction to its methodology. Beverly Hills, CA: Sage Publications, Inc.

LaCompte, M.D., \& Goetz, J. (1982). Problems of reliability and validity in ethnographic research. Review of Educational Research, 52(1), 31-60.

Lee, V.E., \& Frank, K.A. (1990). Students' characteristics that facilitate the transfer from two-year to four-year colleges. Sociology of Education, 63(2), 178-193.

Lee, V.E., Mackie-Lewis, C., \& Marks, H.M. (1993). Persistence to the baccalaureate degree for students who transfer from community college. American Journal of Education, 102(1), 80-114.

Lunneborg, A.E., \& Lunneborg, P.W. (1976). Characteristics of university graduates who were community college transfers. Journal of College Student Personnel, 17(1), 61-65.

Macdonald, J.B. (1962). Higher education in British Columbia and a plan for the future. Vancouver, BC: University of British Columbia.

Medsker, L., \& Tillery, D. (1971). Breaking the access barrier. New York, NY: McGraw Hill.

Miles, M.B., \& Huberman, A.M. (1984). Qualitative data analysis: An expanded sourcebook. Newberry Park, CA: Sage Publications, Inc.

Nora, A., \& Rendon, L.I. (1990). Determinants of predisposition to transfer among community college students: A structural model. Research in Higher Education, 31(3), 235-255.

Pascarella, E.T. (1986). College environmental influences on learning and cognitive development: A critical review and synthesis. In J.C. Smart (Ed.), Higher education: Handbook of theory and research, Vol. 1 (pp. 1-62). New York, NY: Agathon Press.

Pascarella, E.T., Edison, M., Nora, A., Sierra Hagedorn, L., \& Terenzini, P.T. (1998). Does community college versus four-year college attendance influence students' educational plans? Journal of College Student Development, 39(2), 179-193. 
Pincus, F. (1986). Vocational education: more false promises. In L.S. Zwerling (Ed.), The community college and its critics. New Directions for Community Colleges, 54(2), 41-52. San Fransisco, CA: Jossey-Bass.

Prager, C. (1993). Transfer and articulation within colleges and universities. Journal of Higher Education, 64(5), 539-554.

Report of the Advisory Panel on Future Directions for Postsecondary Education. (1996). Excellence, accessibility, responsibility. Toronto, ON: Ministry of Education and Training.

Report of the Provincial Access Committee. (1988). Access to advanced education and job training in British Columbia. British Columbia: Ministry of Advanced Education and Job Training.

Report on the Task Force on Advanced Training. (1993). No dead ends. Report of the task force on advanced training to the Minister of Education and Training. Toronto, ON: Ministry of Education and Training.

Report of the Task force on Standards and Processes. (1997). Vancouver, BC: B.C. Council on Admissions and Transfer.

Rich, I.A. (1979). Counseling the transfer student: Myths and realities. Journal of College Student Personnel, 20(2), 175-176.

Rindfuss, R.R., Swicegood, C.G., \& Rosenfeld, R.A. (1987). Disorder in the life course: How common and does it matter? American Sociological Review, 52(3), 785-801.

Sandeen, A., \& Goodale, T. (1976). The transfer student: An action agenda for higher education. (ERIC Document Service No. ED 154 750).

Small, J.M., Vaala, L.D., \& Tyler, D. (1989). College-to-university transfer: Status and issues in Alberta. Paper presented at the Annual Conference of the Canadian Society for the Study of Higher Education, June 3-5.

Swift, J., Jr. (1986). The community college transfer and "plus two" programs: Access to a baccalaureate degree in four years? Community/Junior College Quarterly, 10(4), 307-316.

Tinto, V. (1975). The distributive effects of public junior college availability. Research in Higher Education, 3(3), 261-274.

Townsend, B.K. (1995). Community college transfer students: A case study of survival. The Review of Higher Education, 18(2), 175-193.

Townsend, B.K., McNerney, N., \& Arnold, A. (1993). Will this community college transfer student succeed? Factors affecting transfer student performance. Community College Journal of Research and Practice, 17(5), 433-443.

Tyler, D., \& Small, J.M. (1990). Persistence of college transfer students. Alberta Journal of Educational Research, 36(2), 181-189. 
Vaala, L.D., \& Holdaway, E.A. (1989). The college to university experience: Satisfaction and success of students who transfer. Alberta Journal of Educational Research, 35(2), 171-1886.

Velez, W. (1985). Finishing college: The effects of college type. Sociology of Education, 58(3), 191-200.

Velez, W., \& Javalgi, R.G. (1987). Two-year college to four-year college: The likelihood of transfer. American Journal of Education, 96(1), 81-92.

Whittaker, D.G., \& Pascarella, E.T. (1994). Two-year college attendance and socioeconomic attainment. Journal of Higher Education, 65(2), 194-210.

Willingham, W.W. (1985). Success in college. New York, NY: College Entrance Examination Board.

Wolcott, H.F. (1973). The man in the principal's office: An ethnography. New York, NY: Holt, Rinehart, Winston. 